\title{
Argentine pediatrics in the coming years
}

Pediatrics has always been characterized by the biopsychosocial approach of all issues related to childhood and adolescence.

With this extended perspective, the care of pediatric patients implies the need for our involvement in the social determinants of the health-disease process, understanding wellbeing not only as the absence of disease, but rather aiming for children and adolescents to be able to reach their maximum potential for growth and development, in a setting of support, affection, and quality education.

In the coming years, as pediatricians, we will have to face serious health care consequences, resulting from the social and economic damage caused by the SARS-CoV-2 pandemic. In Argentina, more than $50 \%$ of children and adolescents are currently living in poverty, with deficiencies in their nutrition, mental health, immunizations, and education. More than ever before, we will have to practice a humanized medicine, with a great deal of empathy towards our patients and their families.

Current knowledge on the "first 1000 days" concept indicates that these early life moments greatly determine health throughout the course of an individual's life. This highlights even more the role of pediatricians, convinced that the true prevention, for instance, of adult noncommunicable chronic conditions (one of the main public health problems worldwide) begins in childhood, and that pediatricians' advice and attitude are still deeply respected by society in general.

Mandatory social distancing has deepened and evidenced Argentina's serious educational problems, underscoring the great difference in opportunities between those who can access curricular contents remotely and those who were not able to get them due to lack of internet connection and/or devices. This serious educational consequence is further exacerbated by the loss of the school as a setting for social development and emotional support among our patients.

As society, with the lack of in-person school attendance, we have lost a very important "social capital" for pediatric patients' support and education, especially in the most vulnerable sectors. This clear social consequence is even more evident among adolescents who, after losing the continuous connection with the educational setting, are more exposed to social problems typical of this stage of life (violence in all its forms, problematic substance use, unintended pregnancies, sexually transmitted infections).

Pediatricians are forced to defend this critical space for the adequate development of children and adolescents, by accompanying health and educational authorities in order to create the best safety conditions in the school setting, convinced that health and education are two indivisible rights from a pediatric standpoint and that school is where this concept is best secured and developed.

Communication and knowledge technologies have achieved a very important boost in these years of pandemic, affecting two critical aspects of medical practice. They have facilitated access to updated scientific information and the remote implementation of different continuing medical education activities. In addition, from the health care perspective, they have helped to stay in contact with patients in a setting of mandatory social distancing. Although this has facilitated visits, it should not overshadow the better quality of face-to-face consultations in general pediatrics, in which we may fully apply the biopsychosocial concept while accompanying children and adolescents and their families, through verbal and non-verbal language and an adequate physical examination.

These challenges for pediatrics in the coming years will have to be faced by simultaneously updating and implementing in health care practice the new knowledge developed by translational medicine, in which different disciplines work together to produce new evidence in order to better understand biological phenomena and access new diagnostic and therapeutic options. Likewise, pediatric research will have to continue generating the best knowledge and guidelines to address our daily problems.

Without a doubt, from this comprehensive perspective, the role of pediatrics in Argentina in the coming years will require a major effort on our part, but our patients and their families, who expect the best from us, fully justify our ongoing hard work in order to honor the main purpose of the Sociedad Argentina de Pediatría: "Striving for a healthy childhood and adolescence in a better world." 
In addition, we must remember that pediatrics is not only a medical specialty, but "a way of being" that distinguishes us within the medical universe.

Omar Tabacco

President

Sociedad Argentina de Pediatría

http: / / dx.doi.org/10.5546/ aap.2021.eng.290

To cite: Tabacco O. Argentine pediatrics in the coming years. Arch Argent Pediatr 2021;119(5):290-291.

\section{REFERENCES}

- Suplemento Covid19 en Pediatría. Trabajo conjunto Comités, Subcomisiones y Grupos de Trabajo dela Sociedad Argentina de Pediatría. Arch Argent Pediatr 2021.

- Documento Sociedad Argentina de Pediatría. Documento conjunto de posicionamiento para el regreso presencial a las escuelas. Octubre 2021. Available at: https://www. sap.org.ar/uploads / archivos / general / files_documentoconjunto-escuelas-covid_1602694567.pdf

- Documento Conjunto Intercomités Sociedad Argentina de Pediatría y Ministerio de Salud de la Nación. El regreso presencial a la escuela de los Niños, Niñas y Adolescentes
conEnfermedades Crónicas. Orientaciones paralos Equipos de Salud. Marzo 2021.

- Cabana JL, Pedra CR, Ciruzzi MS, Garategaray MG, Cutri AM, Lorenzo C e investigadores asociados. Percepciones y sentimientos de niños argentinos frente a la cuarentena Covid-19. Arch Argent Pediatr 2021;119(4):S107122.

- UNICEF. Encuesta de percepción y actitudes de la población. Impacto dela pandemia Covid-19 en las familias con niñas, niños y adolescentes. 2021. www.unicef.org.ar

- UNICEF. Estudio sobre los efectos de la Salud Mental en niños, niñas y adolescentes por Covid-19. 2021. www. unicef.org.ar

- Documento conjunto Sociedad Argentina de Pediatría, Ministerio de Salud de la Nación y Dirección de Control de Enfermedades Inmunoprevenibles. Recupero del Calendario de Vacunación. Mayo 2021.

- Torres F, Domíngez P, Aruanno ME, Macherett MJ, Nocent ES, Risoli L, Sasso M, Cabello C, Seoane M. Impacto de la pandemia por SAR-Cov-2 en la administración de vacunas del Calendario Nacional de Inmunizaciones en menores de 2 años. Arch Argent Pediatr 2021;119(3):198-207.

- Lachman P. Where to make a difference: research and the social determinants in pediatrics and child health in the COVID-19 era. Pediatric Research 2021;89:259-262.

- Universidad Católica Argentina. Observatorio de la Deuda Social Argentina. Nuevos retrocesos en las oportunidades de desarrollo de la Infancia y la Adolescencia. Tendencias antes y durante la Pandemia Covid-19. Junio 2021.https: / / www.uca.edu.ar/es / observatorio-de-la-deuda-socialargentina. 